\title{
Accounting and Finance
}

Mobile Banking Adoption: An Exploration of The Behavioural Intention of Consumers in Ireland Philip McGovern, Jonathan Lambert, Michael Verrecchia

Individual Tontine Accounts

Richard K. Fullmer, Michoel J. Sabin

State Pension Reform: What Have They Accomplished?

Martin Hanby, Robert Tennant, Srinidhi Kanuri, Robert Mcleod

The Effect of Institutional Ownership on Innovation: New Evidence

Chunlai Ye, Lin-Hui Yu

The Popular Financial Reporting for Hybrid Organization: A Solution to a Tricky Accounting Problen Silvana Secinaro, Valerio Brescia, Davide Calandra, Federico Chmet

Using Movie Clips to Help Teach Accounting Principles

Tim Creel, Veronica Paz, Kelli Horne

An Examination of Gender Diversity and Editorial Boards in Finance Patricia Hatfield, Timothy A. Kruse

Credit-Based Insurance Scores and the Cost to Consumers

Cleveland Stiff, Reginald L. Bell, Sudhir Tandon

Artificial Intelligent Credit Risk Prediction: An Empirical Study of Analytical Artificia Intelligence Tools for Credit Risk Prediction in a Digital Era

Diederick van Thiel, W. Fred van Raaij

Earnings Quality and the Likelihood of Material Misstatement in the Financial Statements John Trussel

Lending Standards, Bank Risk-Taking, and Monetary Policy

Maggie apRoberts-Warre

How Intangible Assets Affect the Corporate Financial Performances and 